\title{
THE ORIGIN AND DEVELOPMENT OF GARDEN CITIES - AN OVERVIEW
}

\author{
Dragica Gatarić*1, Marija Belij*, Bojan Đerčan**, Dejan Filipović ${ }^{*}$ \\ * University of Belgrade - Faculty of Geography, Belgrade \\ ${ }^{* *}$ University of Novi Sad, Faculty of Sciences, Departament of Geography, Tourism \\ and Hotel Management, Novi Sad
}

\begin{abstract}
An overview of garden city development as well as its significance in urban planning, are given in this paper. The garden city idea, which had a major role in the 20th century urbanism, was born in London. The author of this concept is Ebezener Howard who is considered a pioneer of modern urban planning.
\end{abstract}

Keywords: Garden city, Ebenezer Howard, urban planning, special structure of the city.

\section{Introduction}

The intensive development of cities, especially large urban agglomerations, began under the influence of the industrial revolution in the $19^{\text {th }}$ century. Thus, the end of the $19^{\text {th }}$ and the beginning of the $20^{\text {th }}$ century is characterized by "urban explosion" when in scientific and professional opinion special attention was paid to the spatial expansion of the city, its geographic and traffic position, and its inception and morphological characteristics. At that time, the largest urban agglomerations were formed mainly in the mining regions and favorable traffic positions. Thus, the industry that indirectly implies processes of concentration and centralization of people, goods, capital, etc. is the main focus of economic development. In addition, the $19^{\text {th }}$ century is often considered the golden age of

1 Corresponding author: D. Gatarić, University of Belgrade - Faculty of Geography, Studentski trg 3/III, Belgrade; e-mail: gataricgaga@gmail.com 
utopia, when the speed of urbanization, i.e. industrialization adversely affected the environment and structural characteristics of human society. Consequently, the need for reforms arised. One of the first reformers to contribute to urban development was Robert Owen, the utopian reformer, who proposed the development of smaller communities on lands suitable for the industry and agriculture development in order to sustain the human community, which would, inter alia, exclude socioeconomic segregation, and thus reduce the differences in the city's social topography. In his plans of the settlements, his attempts to define the urban development nucleus in relation to the industry are highly visible. His followers, above all Furia, had the idea of a harmonious society with the aim of minimizing the impact of industrialization. Consequently, many experts introduce different principles into urban planning in order to create a "healthy" environment on one hand, as well as proposals for addressing socio-economic and other problems that lead to the gap between urban and rural areas, on the other. Owen and Furia's ideas, cities based on a cooperative social community, were used by Ebenezer Howard for the conception of an entirely new theoretical concept of a garden city or a balanced urban environment (Choay, 1978).

\section{Howard's concept of a garden city}

Garden city concept played a very important role in the urban planning of the $20^{\text {th }}$ century. Its author, Ebenezer Howard, is considered one of the pioneers of modern urban planning. In fact, his concept of the garden city was the result of a reaction to the unplanned development of urban environments in the $19^{\text {th }}$ century (Ćorović, 2009). Howard created the concept of a garden city under the influence of geographer Peter Alexeyevich Kropotkin's and economist Alfred Marshall's idea. At the end of the $19^{\text {th }}$ and early $20^{\text {th }}$ centuries, Kropotkin predicted the impact of electricity and the development of communication technology on decentralization in urban areas, and that urban residents would enjoy both rural and urban lifestyles at the same time. On the other hand, Marshall has initiated the planned construction of new cities in order to slow down the increase in social costs caused by the industry concentration in cities (Jovanović, 2005). Howard used their ideas and proposed the establishment of a new city type in order to remove/reduce the differences between rural and urban settlements. Hence, the idea of a garden city has arisen, let's say, at a time of urban identity, uncontrolled urban growth and expansion, as well as weak or broken links with its surroundings (Šečerov, 2012). In his book Garden Cities of Tomorrow, published in 1898, Howard raised the issue of decentralization of major cities, i.e. the founding of green cities around the home town. Among other things, he proposed the construction of garden cities that would enable their spatial- 
urban planning to create an environmentally friendly environment. He wanted this city to have the economic and cultural advantages of city life as well as ecological advantages of rural areas. He realized that the great city ruins itself with its own spatial-demographic growth. Population growth, traffic congestion and inaccessibility to the most important institutions led Howard to the idea of creating a new type of city, which in its growth would not experience "apoplexy in its center and paralysis on its periphery" (Mumford, 2006, p. 548). Based on this, the concept of a garden city must be planned to suit its citizens, as an independent community of a certain area and population. According to the original Howard's concept of the garden city, there would be approximately 32,000 inhabitants, of which 2,000 would live in a green/agricultural area of about 2,400 ha. If the garden city would reach its capacities by its spatial and demographic development, then a new garden city would be built on the outskirts of that home city. He was aware that the congestion of the city would not be solved by the expansion of residential buildings, but by its complete decentralization (Mirkov, 2007). The spatial plan of the garden city would be radially-concentric, where six boulevards would stretch radially from the central city square (circular in shape with park and public buildings), dividing the city into six equal housing units. Each housing quarter would have one school and about 5,000 inhabitants. Factories, workshops, warehouses, etc. would be located along the city's periphery, alongside a circular railroad that would surround the whole city. According to the principle of zoning, the city would be surrounded by a "spatial wall" - a green belt (intended for agriculture and recreation), whose function would be to limit population and spatial expansion (urban growth), as well as to provide the urban population with immediate proximity to the greenery and the agricultural environment. It would also be a sports and recreation zone. This concept of the "green ring" was being applied later on in many cities both in Europe and around the world. Actually, Howard introduced zoning in the city planning process, i.e. industrial zone, residential zone, public space and green area with the idea that they should be spatially separated units. However, zoning was not a problem in garden cities because a new city would be formed when the former would reach its spatial and demographic capacities. But given the degenerate development of cities, especially large urban agglomerations, today we cannot talk about separate spatial-functional entities because they are interconnected and complement each other. Howard's concept of a garden city is not based solely on spatial expansion, but on the population expansion as well, the principle of multiplication, so that the overbearing population will "go" to form a new center at a sufficient distance from the original one that would be surrounded by a green area. Spatial "multiplication" (6-7 small towns) around the central garden city would form the so-called polycentric social city with approximately 250,000 inhabitants (Jovanović, 2005, pp. 87-88). In administrative-territorial terms, these would be separate cities, i.e. "a cluster of cities". 
According to Howard's plan, direct traffic lines should connect each city to the others, in order for the population to be transported from one city to the other without any difficulties and shortest amount of time. So, the traffic component of development gave Howard the real basis for "decentralized urban development" (Mirkov, 2007, p. 319). This type of city was later called the "regional city" by Clarens Stein and his followers (Mumford, 2006). Howard's garden city idea was realized in 1903 when the construction of an "experimental" settlement, Letchworth, began $40 \mathrm{~km}$ from London, and in 1919 when Velvin was constructed. The idea of building the first garden city was created, i.e. it was an important decision which was brought after the first conference dedicated to the garden cities of Burnville in 1901 (Ćorović, 2009). Thus, Howard's idea of a garden city became a part of the Greater London Plan. The main objectives of this plan were the following: spatial restriction of central parts of London, its relief and spatial expansion achieved by the construction of new settlements (satelliteization) in its surroundings which would be surrounded by a green area, the central city and the new administrative arrangement of the London region (Vresk, 2002).

He believed that urban expansion and spatial joining of suburban settlements into a unified urban fabric could be halted by planned decentralization and the construction of autonomous cities. However, such a concept of "city planning", in view of the constant and changing process in large agglomerations and its peripheries, is hardly feasible in practice. Thus, the basic idea of Howard's plans was a combination of urban and rural spaces, avoiding shortcoming that can occur in these environments and taking the best both from urban and rural environments and merging them into a single entity. Consequently, his vision was bifocal, because it encompassed both the city and the area outside it, i.e. the rural areas that are not static categories. It can be said that he was a critic of the industrial city because he was aware of the fact that, in industrial societies, the rural environments from the point of view of socio-economic opportunities do not have such an "attraction power" that the cities have (Mirkov, 2007). Accordingly, the possibility of employment in industry, mining, traffic and other service activities was the initial capsule for spatial redistribution and social restructuring of the population. Thus, rural flight into cities is a contiguous phenomenon of industrialization, where massive and rapid housing construction, as well as the development of industrial zones on the outskirts of the city, prompted the need for a more humane development of the city, as well as finding a series of planned measures of controlled development and arrangement of large agglomerations. He maintained that the redistribution of population into cities can only be prevented if life conditions were created in a way which would spontaneously attract the population. Explaining the benefits of the city and the village, Howard pointed out to the existence of The Three Magnets: Town, Country and Town-Country, highlighting the pull and push factors in 
cities and villages affecting migration movements of the population. He thinks that "every city can be seen as a magnet, and every individual as a needle". The magnet "town-country" is viewed as two magnets, both tending to attract the population..." (Howard, 1965, p. 46), and the magnetic attraction of the Town is comprised of high wages, a greater possibility for economic activities, rich and diverse social life. The disadvantage of this magnet is the high rental costs and the generally high cost of living, overtime work, the distance between the place of work and the place of residence, the lack of community, polluted air and the poor neighborhood. The Village could attract the population close to a "healthy" environment or low rental costs. However, village residents have the opportunity to deal exclusively with agriculture, earnings are very low, and the lack of social life further weakens the magnitude of this magnet. This means that neither the magnet Town nor the magnet Village can provide a harmonized life. By combining these two magnets into a magnet called Town-Village, a garden city, uniting the Town and the Village, society and nature with all its differences and similarities that complement each other and attract more inhabitants than the other two magnets (Mirkov, 2007, p. 315), would be created. Howard also pointed out to the social control over the land. He considered that whoever controls the city land, plans the spatial-functional development, determines the timing of construction and provides all the necessary services, at the same time controls the very "destiny" of the city. This control should have a public body that is responsible for the welfare of the whole (Turza, 1998 and Mumford, 2006). Similarly, Democrat Tomas Spens, as well as philosopher and sociologist Herbert Spenser, were proponents of social ownership of the earth (Ćorović, 2009). Such a concept actually represents a milestone in the perception of the city economy and city administration (Mumford, 2006).

So, Howard's cities were individually conceived with a single center, while polycentric planning only concerned the connection of several garden cities. In the garden cities, cultural and ethnic differences of the population must be respected, since they play an important role in determining the quality of the society in the garden cities, as well as on the social topography of the city. Huard's ideas about the development of the city had a significant impact on many of the sociologists and urban planners, including Unwina, Stein and Mumford, who, among others, contributed to the development of urban planning theories. Mumford (1986) supported the concept of garden cities precisely because of the decentralization of space and local government. He considered that zoning is not a sustainable way of urban planning unless new centers (public spaces and public institutions) are established within cities (Mumford, 2006). In addition, Howard's idea of a garden city was later developed by Gidis, establishing the concept of an urban region, and Hirschmann, Peru et al. pointing out the process of polarization and the dynamics of regional change through the poles of 
integration, growth and development. Hirschmann believes that polarization is not a consequence of the development of an overall economy, but that it is conditioned by the action of one or more groups of similar factors. He believes that interregional equality (equality between developed and underdeveloped regions) can only be achieved by the relocation of the population, redistribution of investments and funds for material production and public consumption. In contrast, the theory of growth and development, developed by Peru, is based on the fact that territorial accumulation and concentration of investments, people, information exchange is done through the poles (points) of growth and development. Growth that has various effects on the economic development of the state occurs in the poles and it does not occur everywhere simultaneously. According to him, a pole is a development focus in which economic units, which have the function of "development engines", are concentrated, where the dominant economic units influence the development and attraction of other economic units (Tošić, 2012).

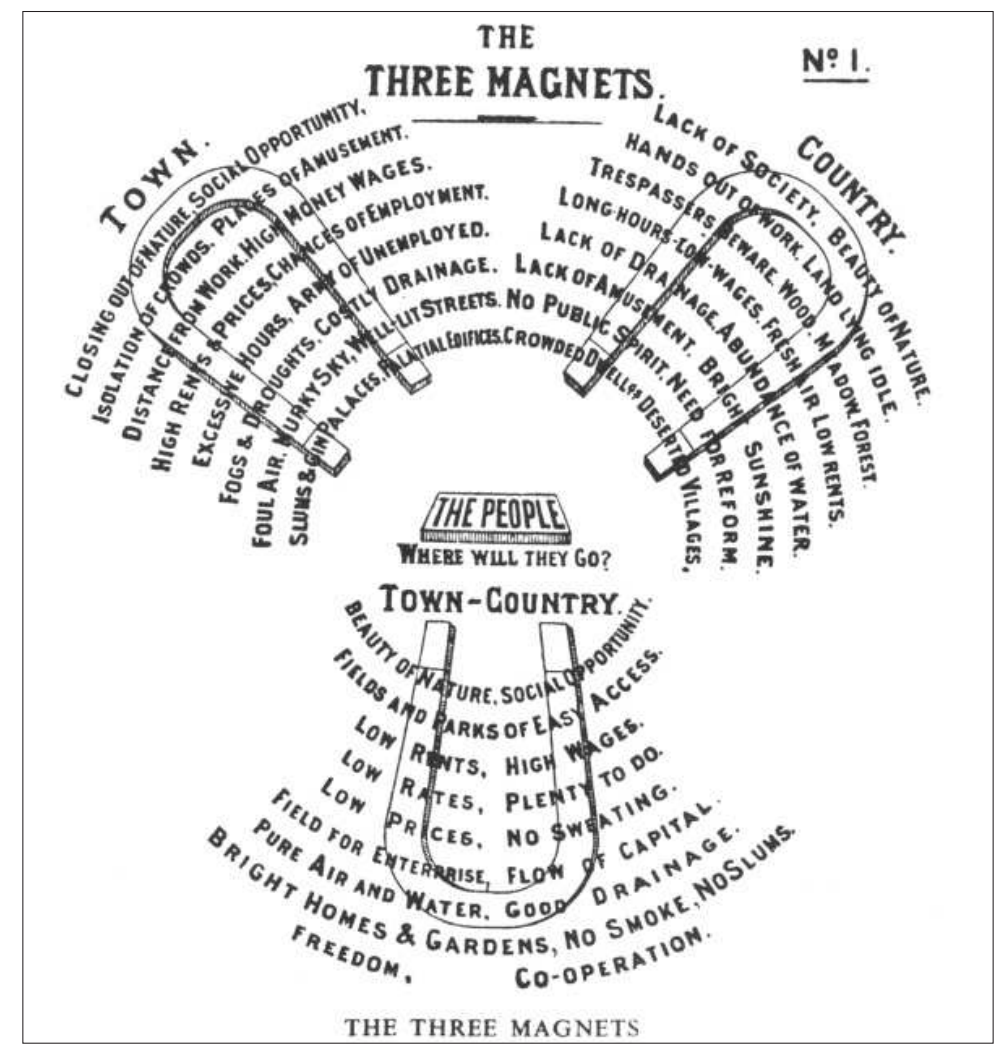

Figure 1. Howard's 'three magnets' diagram

(Source: Uxcester gardencity, Wolfson Economics Prize Submission 2014) 


\section{The Development of Garden Cities Worldwide and in Serbia}

The application of variations of the Howard concept of a garden city, especially until the 1960s, was the most intensive in many European countries during the restoration of the cities, especially after the First and Second World War (Mirkov, 2007). The first experimental cities were Lechworth (started 1903) and Velvin (1919) near London, whose planners were Raymond Unvin and Bari Parker. Since Velvin is closer to London than Lechworth, it has rapidly grown attracting industrial investors and new residents, but on the other hand he had a higher share of those people commuting to London. Accordingly, Velvin was increasingly considered to be a city-satellite, and not a real garden city. Similar ideas were developed in Germany, and in 1909, the town of Hellerau near Dresden (Vresk, 2002) was built. In the early $20^{\text {th }}$ century, Howard's ideas and principles of the garden city had a great influence on the Dutch, who are rightly said to have urban culture, while they were building Hilversum, as well as other smaller satellite settlements in Frankfurt on the Main, etc. (Mumford, 2006).

The first serious changes to the Howard's Garden City concept, under the influence of Raymond Unwin, took place in the United Kingdom between the two world wars. Then they switched to the concept of satellite cities, which were exclusively used for housing. This would prevent a concentration in the home town, i.e. decentralization. The main reason for the abandonment of the city-satellite concept after the Second World War and the creation of a new urban concept, i.e. "new cities", was that satellites were far removed from their metropolises and their residents who worked in their home or neighboring metropolises had difficulties commuting. After the Second World War in England, twenty settlements were built around Glasgow, Birmingham, Liverpool, Manchester, etc. in the form of a simplified model of garden cities (Jovanović, 2005).

Thanks to the planners, the implementation of the Garden City concept in the United States is evident in Radburn, New Jersey, which was established in 1929. The private association (Radburn Association) was allowed to manage and tax the inhabitants of Radburn in order to control the development and the appearance of the settlement. Basic planning characteristics of Radburn are residential blocks with internal greenery as well as the use of underpasses for the purpose of separating automobile and pedestrian traffic (Mirkov, 2007). In 1934, the Department for the Settlement of the Suburbs was established in the United States so that a certain number of experimental garden cities or "greenbelt towns" could be built on the territory of the whole country. However, the Department was cancelled because there was no cooperation of local communities that would be involved in the process of construction of experimental 
garden cities (Mumford, 2006). The application of the concept of a garden city in the planning and organizing of USA settlements prevented the suburbanization process and the newly established cities themselves became the suburbs of larger cities.

Ebenezer Howard earned a lot of supporters in Russia too, where, even in specific social circumstances, materialization of his idea was achieved. Trying to adapt Howard's theory to Russian conditions, in 1912, architect Vladimir Semyonov designed Prozorovka, the first garden city - a dormitory for employees in the railway, $40 \mathrm{~km}$ away from Moscow. From 1912 to 1917 Prozorovka was a model for the future construction of garden settlements in Russia.

However, there was also an idea for the construction of suburban settlements around St. Petersburg, but the war and the revolution made it impossible for those plans to be realized. There was also a project for the construction of the settlement "Kaunis and Taivola" in the vicinity of Karelia, but this plan has not been implemented. Plans for the reconstruction of Moscow and the environment were also inspired by Howard's concept of garden cities. The architect Boris Sakulin, in 1922, in his plan for the Moscow region, considered that any population restriction was artificial and arbitrary. By introducing the heavy industry into his gardens, he thoroughly rejected Howard's assumption of a healthy living environment in the city (Mirkov, 2007). Howard's Garden City concept was partly applied in Australia when the Canberra was built, when seeking to exclude social segregation. However, some Canberra residential areas were planned according to the financial capabilities of citizens coming from different social classes. Similarly, Perth, an Australian city, has features of a garden city (Mumford, 2006). The concept of "garden cities" did not come to life in its original idea, but it is therefore possible to revitalize them by engaging in a tourist offer, i.e. creating a specific tourist product that would attract a certain profile of tourists. A good example of this practice is the garden city of Tapiola in Finland, which experienced a re-branding due to the celebration of the anniversary. In this way, once forgotten city, life has been restored in an almost forgotten city, and this is precisely thanks to the tourism and tourists who visit this unusual ambience. After completion of the construction phase, Tapiola gained an international reputation and became the "destination of pilgrimage" by architects and other travelers (Manninen, 2003, p. 8), for which the city hired tourist guides who conducted specialized tours (Johansson, 2012). A certain brand that Tapiola represented as a garden city has, over time, experienced changes in terms of architecture and social organization. However, for the celebration of the fiftieth anniversary of its founding, a discussion of its future has come to life. The prevailing opinion was that this city must be preserved as an architectural heritage, and not protect it until it gets quenched and transformed into the "mummified city-museum" (Salmela, 
2003). Similarly, it is possible to make a tourist product from other garden cities, so that they represent a unique whole, which could attract a specific type of tourists. In addition, by designing other tourist facilities, as well as by arranging accommodation for tourists in the cities themselves, a complete tourist offer could be created, so that tourists can feel the unique atmosphere of garden cities and what it is like to live in those cities.

At the beginning of the $20^{\text {th }}$ century, the concept of a garden city was introduced into the urban discourse of our country. The attempt to build garden cities using Howard's concept in Serbia is evident in the construction of Nova Kolonija in Kragujevac and Profesorska Kolinija in Belgrade. The idea of forming residential colonies in Belgrade, according to the Garden City concept, has arisen from the 1923 Belgrade Master Plan (Ćorović, 2009).

The spatial structure of Profesorska Kolonija is characterized by radial, diagonal and arched streets with circular squares and irregular parcels and quarters. It encompassed the present streets of Ljuba Stojanović, Stojan Novaković and Jaša Prodanović, and later expanded spatially to other streets bordered by the streets of Cvijić, Zdravko Čelar, Mitropolit Petar and Despot Stefan (Bojanić, 2012). The theoretical basis of the Garden City concept in Belgrade was laid by the architects Jan Dubovi, followed by Branko Maksimnović, who is well known to the urban public as a good connoisseur of the concept of a garden city and by his interpretation of the German experience, which he transformed into a model of possible application in Slovenia, as well as Slobodan Ž. Vidaković, who highlighted the sociological aspect of the garden city and the implementation of this concept in our conditions (Ćorović, 2009). Profesorska Kolonija, as a whole, previously protected by the municipality of Palilula, is on the list of the Institute for the Protection of Cultural Monuments of the City of Belgrade.

\section{Conclusion}

Howard's Garden City concept played a very important role in urban planning in the first half of the $20^{\text {th }}$ century, beginning with the construction of the first garden cities of Letchworth and Velvin, as well as the later socalled "new cities" in England. The concept, which was applied during the reconstruction of cities after the two world wars, had its earliest supporters throughout Europe, including the Balkan countries, as well as in Russia and the United States. Over time, the originally Howard's idea was redefined by planners Raymond Unwin and Bari Parker and implemented in the construction of garden suburbs, satellite cities and new cities that could have the function of the developmental poles. Accordingly, several variants of the garden 
city were applied. Due to many difficulties which appeared in practice, many ideas were modified and many differed greatly from his original ideas, and over time, this concept was abandoned as utopian. Howard's ideas, which were aimed at solving the problem of isolation, overcrowding, ecological problems, unemployment and unequal distribution of goods as well as theoretical and practical contribution to urban planning, by establishing garden cities, did not prevent the concentration of population and capital. It can be said that he underestimated the gravitational force of the city center.

Thus, Howard's ideas failed to stop the uncontrolled population, industrial explosion, and the expansion of land exploitation, which were detrimental to large urban agglomerations. First of all, the focus is on the unplanned expansion of the suburbs, which is a shameful "surrogate" for a planned city and its region. Howard's concept would undoubtedly have a significant impact on the balance between urban communities and the rural environment, as well as the creation of such an environment in cities that would tend to raise environmental awareness of individuals. But, given the constant and varied phenomena and processes in large agglomerations and its peripheries, this concept is hardly feasible in the practice of urban planning. A garden city can only come to life if political and economic institutions are directed towards spatial and regional reconstruction and development. In addition, it can rightly be said that Howard also had a solid sociological concept of the dynamics of rational urban development. In his city development concept, he not only avoided the weaknesses of specialized suburbs and specialized industrial cities, but also suggested and tried to eliminate the possibility of their destruction due to unlimited growth. The implementation of the idea of garden city into the urban planning in the $20^{\text {th }}$ and the beginning of the $21^{\text {st }}$ century occurred gradually, and the construction of new cities remains a very important and significant planning measure and action to partially solve urban and other issues.

\section{Acknowledgement}

The paper is the result of research projects 176017 and 176020, which are financed by the Ministry of Education, Science and Technological Development of the Republic of Serbia.

\section{References}

Bojanić, B. (2012). Da li je narušen concept vrtnog grada - Urbanizam i arhitektura u Profesorskoj koloniji. Arhitektura i urbanizam, 36, 27-35.

Vresk, M. (2002). Grad i urbanizacija. Zagreb: Školska knjiga. 
Jovanović, M. (2005). Međuzavisnost koncepta urbanog razvoja i saobraćajne strategije velikog grada. Beograd: Univerzitet u Beogradu - Geografski fakultet.

Johansson, M. (2012). Place Branding and the Imaginary: The Politics of Re-imagining a Garden City. Urban Studies 49(16), 3611-3626.

Turza, K. (1998). Luis Mumford - Jedna kritika modernosti. Beograd: Zavod za udžbenike i nastavna sredstva.

Mumford, L. (2006). Grad u istoriji. Beograd: Biblioteka "Temelji".

Mumford, L. (2010). Kultura gradova. Novi Sad.

Manninen, A. (2003). Tapiolan idealistinen mallikaupunki tayttaa syksylla 50 vuotta. Helsingin Sanomat, 2 August, section B.

Mirkov, A. (2007). Vrtni gradovi Ebenezera Hauarda. Sociologija, 59(4), 313-332.

Salmela, M. (2003). Alkuperainen Tapiola oli pienempi kuin moni luulee, Helsingin Sanomat, 11 August, section B.

Tošić, D. (2012). Principi regionalizacije. Beograd: Univerzitet u Beogradu - Geografski fakultet.

Ćorović, D. (2009). Vrtni grad u Beogradu. Beograd: Zadužbina Andrejević.

Uxcester gardencity, Wolfson Economics Prize Submission 2014, 29 pp.

Howard E. (1965). Garden Cities of To-Morrow. Cambridge: The M.I.T. Press.

Choay, F. (1978). Urbanizam - utopija i stvarnost. Beograd: Gradjevinska knjiga.

Šećerov, V. (2012). Strateško planiranje grada. Beograd: Univerzitet u Beogradu Geografski fakultet, Asocijacija prostornih planera Srbije. 